\title{
Enhancing non-verbal communication through gamification: the case of treasure hunt
}

Aprimorando a comunicação não verbal por meio da gamificação: o caso da caça ao tesouro

Mejorar la comunicación no verbal a través de la gamificación: el caso de la búsqueda del tesoro

Michelina Manzillo

\begin{abstract}
An adapted version of "treasure hunt" game can help participants' to improve nonverbal skills and understand the crucial role of servant leadership. This case-work with ten participants outlines how individuals tend to use traditional rules when they consider to be aware of a game/situation. However, in this casework, was observed how in "learning-by-doing", individuals managed to leave their comfort zone and learn the new rules while practicing them. Furthermore, this caseworks helped to teach the importance of non-verbal communication skills and the soft role of servant leaders.
\end{abstract}

Key words: Recreational therapy. Communication. Leadership. Frugality.

Resumo: Uma versão adaptada do jogo de "caça ao tesouro" pode ajudar os participantes a melhorar as habilidades não-verbais e compreender o papel crucial da liderança servil. Este trabalho de caso com dez participantes descreve como os indivíduos tendem a usar as regras tradicionais quando consideram estar cientes de um jogo / situação. Porém, neste caso, observouse como no "aprender fazendo", os indivíduos conseguiram sair da sua zona de conforto e aprender as novas regras praticando-as. Além disso, esse estudo de caso ajudou a ensinar a importância das habilidades de comunicação não-verbal e o papel suave dos líderes servos.

Palavras - chave: Terapia recreativa. Comunicação. Liderança. Frugalidade.

Resumen: Una versión adaptada del juego serio de "búsqueda del tesoro" puede ayudar a los participantes a mejorar sus habilidades no verbales y comprender el papel crucial del liderazgo de servicio. Este trabajo de caso con diez participantes describe cómo los individuos tienden a usar las reglas tradicionales cuando consideran estar al tanto de un juego / situación. Sin embargo, en este trabajo de caso, se observó cómo en el "aprender haciendo”, los individuos lograron salir de su zona de confort y aprender las nuevas reglas mientras las practicaban. Además, estos casos prácticos ayudaron a enseñar la importancia de las habilidades de comunicación no verbal y el papel blando de los líderes de servicio.

Palabras - clave: Terapia recreativa. Comunicación. Liderazgo. Frugalidad.

\section{Introduction}

Recreational therapy can benefit of gamified initiatives to support skills' development in patients and in participants' activities. In fact, "Recreational therapy (RT) uses leisure activities to help people with specific health conditions improve their skills, abilities, overall health, and emotional well-being. It helps to integrate the skills that the individual acquired in his/her environment/community setting. The 
modalities to convey RT programs and activities are heterogeneous: they can be related to creative arts (such as painting, music, drama, singing), sports, physical therapy activities (such as locomotion, sensorial development, motricity, cognition and communication). The goal of RT for patients is to live genuine recreative experiences, enjoying the "journey" in order that the activity does not ends and is not finished once the individual completes it. In fact, participants have the right to enjoy their lives and experiences even if they do not reach the goals and the expected outcomes decided for their treatment plan².

Nowadays, there is an ongoing debate on if RT intervention is a tool to achieve outcomes or if it is a platform to provide leisure experiences. RT has experienced flourishing research activities and experimentations, which constantly contribute to the development of new models and approaches. Experimenting new activities, is indeed key to contribute to the development of the discipline in order to provide the best solutions to the clients.

An adapted version of "treasure hunt" was used, already observed in an Applied Behavior Analysis (ABA) class, in order to work on patients' non-verbal communication skills and in empowering participants' during the gamified session. Furthermore, since this adapted version of treasure hunting needs specific roles, the article shows how this activity is useful to enhance leadership. In fact, as it will be showed, the activity teaches Servant Leadership and how a Leader can be so even without adhering to stereotyped characteristics on Leadership (ex. an extensive use of "power" using verbal and directive orders/commands).

\section{Methods}

A non-participant observation was realized benefiting from observational methodology ${ }^{3}$.

I tested the activity with a group of adults during an experimentation phase of new techniques in recreational therapy's activities. The main goal of the activity is to find all the objects « hidden " in the treasure hunt session, with a particular focus on the "last object". The activity is highly flexible, and it can be adapted in several contexts and places, both indoor and outdoor. As tools, it is recommended to have a basket with small pieces of papers; the small pieces of papers are the only tool that can been used by participants to communicate among them.

Groups' structure: it is necessary to divide the participants in at least two groups. The organizers can decide the criteria for the division. Generally, the distribution criteria can be based on two principles:

1) Skillset and attitudes: to have participants with complementary skills, it is 
possible to select profiles which are heterogeneous. Furthermore, putting in the group profiles with complementary attitudes (ex. an equilibrated mix of calm individuals with proactive personalities), reduces the risk of attrition. Furthermore, equilibrated teams, will avoid that one team will predominate the other team generating frustration.

2) Randomly: when the participants have similar skills and attitudes, or if the organizers to do not know the skills and attitudes of the participants, it is possible to proceed directly with a random draw/selection of the groups.

In this case, the two groups were randomly composed (i.e., with a random draw). They belonged to the same generation, in a range from 24 to 30 years old. On 10 participants, $80 \%$ of the participants were women. They all had a similar background and a tertiary educational record (bachelor degree). Teams should be composed by at least two participants. The winning group is the one finding the objects (including the final one) in less time.

Focus on key roles: the group needs to be composed by at least a Hunter and one Guide. The Guide owns the basket with the small pieces of papers. The guide is informed by the Organizers of the session on the location of the objects to find. The Guide drops the pieces of paper on the floor to guide the Hunters. For example, when the Hunter is close to the object, a significant quantity of paper can be dropped; if the Hunter is far from the object, a less quantity of paper is dropped (NB: they cannot verbally interact). The roles can be inverted at the end of the game to enhance empathy among participants (i.e., a Hunter who faced difficulties in understanding the signals triggered by the Guide, could understand the difficulties of the Guide when he will play his/her role in the second turn).

Expected benefit: the Guide is empowered thanks to his/her responsibility in guiding the Hunter(s). The Guide needs a good perception of the "space " where the activity is taking place. Physically, motricity is not stressed even if both Guides and Hunters need to think and act quickly in order to obtain the objects before the other group; for this reason, the activity is suggested to any kind of patient, even with difficulties in mobility. Furthermore, a sense of cooperation and complicity needs to be generated among team-members, with positive externalities on team building. The exercise also teaches that communication can be "non-verbal " and that movements and the management of the material (i.e., the quantity of paper) are crucial to convey key 
messages to the partner. Focus and concentration are demanded.

\section{Results}

We tested the activity in a meeting room, showing how the exercise can also be undertaken with frugality in smaller and simple places. If outdoor it would be idea, even indoor it is possible to adapt the setting. The objects were hidden in different areas of the room; behind the bin, behind the paperboards, in cupboards. Each object had a suggestion (easy-written) addressing the players to the next step/object to be found. Participants were extremely focused; focus exacerbated by the competition aspect of the activity (i.e. I observed that the teams strongly wanted to win). The activity lasted around 30 minutes.

The participants were 10 testers and with an heterogenous background in the healthcare sector (i.e., educators, nurses, psychologists, physiotherapists). To simplify the procedure, the groups were divided into two groups of five members. Since the beginning of the game, it was evident that a sense of competition was integrated in the group dynamic. As observed in other studies, competition increases motivation and accuracy ${ }^{4}$.

Before to start the game, I briefed all the participants (the two Guides and the Hunters) on their specific roles and how to use the material/tools (i.e. the pieces of papers to communicate). I briefed in private the Guides on "which were" the places where the objects were hidden. I also added that the game would have finished once the first group would have found the final object.

During the session, I observed that even if there was a high level of motivation, there was some confusion on how to "interpret" the amount of paper used by the Guide. There was a subjective element in fact from the Guides' side on "how much paper" had to be used to guide the Hunters. I observed in particular that the Hunters tended to verbally communicate and comment the game among them, moving the attention from the pieces of paper to the “discussions" among Hunters. In 30 minutes, one of the two groups managed to find the final object; while the other one was still looking for the others. I asked a final feedback from participants' in order to improve the session and the methodology.

\section{Conclusions}

Main observations:

1) Treasure hunt is a common game. For this reason, participants tended to play it with a traditional approach and were biased by traditional rules (i.e., with verbal communication).

2) Extroverts / outgoing personalities among Hunters tended to embody a Leadership role in guiding the Hunt.

3) Guides should be Servant Leaders in this activity but they faced problems in 
imposing themselves. Servant leaders are those leaders committed to serve the others. They tend to find "conciliation" among collaborators, bring out the best from colleagues and partners, serving the community $^{5}$ even renouncing to exalt their individuality and visibility in the group. Since usually leadership is associated to power, visibility and “action”, servant leaders could face difficulties in being followed by the rest of the group. In this case, these difficulties were exacerbated from the fact that Leadership was associated to "verbal communication”.

4) Guides were biased by the amount of paper to use (i.e. what a Guide considered "a lot of paper" was not enough for the other Guide)

5) The game session was a "learning by doing". At the beginning there was some reticence in following non-verbal communication instructions. After 20 minutes, Hunters and Guides improved their concentration level and managed to follow all the rules and improve their synergy.

\section{Suggestions:}

1) Be as clear as possible on the rules. Participants already know "treasure hunt" as game and they will tend to ignore the "new rules" of this traditional game. They could also be written / advertised on a poster in the place where the game takes place.
2) Highlight that the Guide is a Servant Leader. “A servant-leader focuses primarily on the growth and well-being of people and the communities to which they belong. While traditional leadership generally involves the accumulation and exercise of power (i.e. even verbal communication) by one at the "top of the pyramid," servant leadership is different. The servant-leader shares power puts the needs of others first and helps people develop and perform as highly as possible". In this case, in fact, the Servant Leader had the role to guide the Hunters to achieve their goals: find the hidden objects. If the participants will be aware on the crucial role of the Guide, they will tend more to follow him/her.

3) Manage frustration with positivity. I observed that participants were frustrated because they "could not" speak and they could not lead the game. Create a positive environment with jokes and acknowledging each other's results: continuously celebrate the achievements ${ }^{6}$.

In conclusion, this adapted version of treasure hunt was positively accepted by participants. It was a good exercise to put participants "out" of their comfort zone. At the end, teams were proud to have learned new skills (performing with non-traditional rules, communication in other ways than verbally). This activity created a good synergy among participants and improved the self- 
esteem of participants (especially of Guides, when they managed to lead participants to achieve their goals). Especially in the aftermath of COVID-19, where several activities are still organized indoor and in limited spaces, it can be organized even in indoor with creativity and frugality, using simple tools. Furthermore, it also teaches Servant Leadership and how a Leader can be so even without adhering to stereotyped characteristics on Leadership ${ }^{7}$.

\section{References}

1. Marney A. White, "The Benefits of Recreational Therapy", Healthline. Available at:

https://www.healthline.com/health/recreationa l-therapy (Accessed on 26/06/2021)

2. Kunstler R.A., Stavola Daly A. (2010), "Therapeutic Recreation Leadership and Programming”, Human Kinetics.

3. Catchpole K, Neyens DM, Abernathy J, Allison D, Joseph A, Reeves ST. (2017), "Framework for direct observation of performance and safety in healthcare", BMJ Qual Saf, 26(12), pp. 1015-1021.

4. Cagiltay, N. E., Ozcelik, E., \& Ozcelik, N. S. (2015). The effect of competition on learning in games. Computers \& Education, 87, 35-41.

5. Hanse JJ, Harlin U, Jarebrant C, Ulin K, Winkel J. (2016). The impact of servant leadership dimensions on leader-member exchange among health care professionals. J Nurs Manag, 24(2), pp. 228-234.

6. Deroo, C. (2006), "What's Right with Me: Positive Ways to Celebrate Your Strengths, Build Self-Esteem and Reach Your Potential", New Harbinger Publications.

7. Sczesny, S., Bosak, J., Neff, D., \& Schyns, B. (2004), "Gender stereotypes and the attribution of leadership traits: A crosscultural comparison", Sex roles, 51(11-12), pp. 631-645.
Information of this article:

Recebido: 26/06/2021

Aprovado: 26/08/2021

Publicado: 06/08/2021

Received: 26/06/2021

Approved: 26/08/2021

Published: 06/08/2021

\section{ORCID}

Michelina Manzillo

https://orcid.org/0000-0001-6482-7662

\section{Conflicting Interests}

The authors declare that they have no conflicting interests.

\section{Como citar esse artigo / How to cite} this article:

Manzillo, M. Enhancing non-verbal communication through gamification: the case of treasure hunt. Arq. Bras. Ed. Fís., Tocantinópolis, v. 4, n. 1, Jan./Jul. p. 101 - 106, 2021. 